\title{
The Impact of the Covid-19 Pandemic on Share Prices and Trade Volume of Shares in Indonesia Stock Exchange
}

\author{
Sri YuliWaryati \\ Faculty of Economics and Business \\ Yogyakarta,Indonesia \\ sriyuliwaryati@janabadra.ac.id \\ NiningWidiyanti \\ Faculty of Economics and Business \\ Yogyakarta,Indonesia \\ nining.wid@janabadra.ac.id
}

\author{
M.G.Suwarni \\ Faculty of Economics and Business \\ Yogyakarta,Indonesia \\ mgsuwarni@janabadra.ac.id \\ AdhikaNirwanNandhya \\ Faculty of Economics and Business \\ Yogyakarta,Indonesia \\ adhikanirwan89@gmail.com
}

\begin{abstract}
Purpose of this study is to analyze the comparison of the average abnormal stock returns received by investors and the average stock trading volume activity before and after the announcement of the Covid-19 Pandemic in Indonesia on March 2, 2020 for companies included in the LQ-45 on the Indonesia Stock Exchange. This study uses the average difference test analysis method, and the data analyzed is the average abnormal return of stocks and the average stock trading volume activity in the short-term period, namely ten (10) days before and ten (10) days. after, as well as long-term period data, namely thirty (30) days before and thirty (30) days after the Covid-19 outbreak was announced in Indonesia. Based on the results of data analysis, it states that for both the short and long term periods there are significant differences in the average stock abnormal return and average trading volume activity of LQ-45 company on the Indonesia Stock Exchange after the announcement of Covid-19 on March 2, 2020, which hit Indonesia compared to before Covid-19 was announced.

Keywords: Covid-19, abnormal return, trading volume, LQ-45, Indonesia Stock Exchange
\end{abstract}

\section{INTRODUCTION}

\section{Background of the Problem}

Economic life is never separated from its connection with the Capital Market. The capital market has an important role in economic life, especially in the process of allocating public funds. The capital market provides a variety of investment vehicles for investors, making it possible to diversify. Investment alternatives provide potential returns with a calculated risk level. Investors' investment decisions are determined by their expectations of the success of a business in the future.

The aim of investors in investing is to maximize returns without forgetting the investment risk factors that must be achieved. Return is one of the factors that motivates investors to invest and is also the courage of investors to take risks for their investments. In essence, investors in investing will try to invest in company shares that are able to provide returns or benefits in the form of dividends and / or capital gains. Efficient investment is an investment that provides a certain risk with a maximum level of return or a certain level of return withminimal

risk[7](Jogiyanto,2016).Microeconomic environment (events or circumstances of issuers, such as performance reports, dividend distribution, changes in corporate strategy or strategic decisions at the General Meeting of Shareholders), macroeconomic environment (environmental changes driven by macroeconomic policies, monetary policies, fiscal policies and government regulations in the real sector and finance), and the non-economic environment (upholding human rights, concern forenvironment, state administrative events that are full of political nuances, natural disasters and non-natural disasters) can have a positive or negative impact on the stability of the conducive climate that investors want to invest in a country, their expectations of every event that occur will be reflected in turmoil or dynamics in the capital market.

One of the non-natural disasters that has a major impact on stock trading on the Stock Exchange is that the Coronavirus Disease 2019 (COVID-19) has become a pandemic, a global epidemic, whichspread across continents. Covid-19 first broke out in Wuhan, China, towards the end of December 2019 (CRC John Hopskin University, 2020). Then a great outbreak in Hubei Province and made China go into lockdown. Almost all provinces there are under quarantine. In less than two months, the core coronavirus has caused 80,000 cases and 3,000 deaths. Starting the third week of January 2020 ,. Covid then crossed to a number of countries in Asia, America, Europe, Autralia and Arika. When this outbreak subsided in China, the Covid-19 transmission actually exploded in a number of countries in America, Europe, Asia, then Africa. As of 8 May 2020, the number of infected cases in the US, Spain, Italy, Britain, Russia, France, Germany, Brazil, Turkey and Iran has surpassed China as the initial epicenter. Meanwhile, in terms of the number of deaths, there are six countries that surpass China, namely: the US, Italy, Spain, France, Britain, Germany, Iran and Belgium. Meanwhile, the number of victims in the Netherlands and Canada has also begun to approach China (Worlddometter, 8 April 2020). 
The COVID-19 pandemic in Indonesia is part of the ongoing coronavirus disease pandemic 2019 (COVID-19) around the world. A positive case of COVID-19 in Indonesia was first detectedtwo people were confirmed to be infected by a Japanese national. As of April 9, the pandemic has spread to 34 provinces with East Java, DKI Jakarta, and South Sulawesi as the most exposed provinces. As of 27 July 2020, Indonesia has reported more than 100 thousand positive cases, the most in Southeast Asia surpassing the Philippines and Singapore. In terms of mortality rates, Indonesia is ranked fifth in Asia with 4,838 deaths.

The panic caused by Covid-19 has an impact on capital market conditions in Indonesia. Since the first case of COVID-19 was announced on March 2, 2020, on that day the JCI closed 91 points $(1.67 \%)$ to the level of 5,361. At that time the JCI trend was indeed bearish. However, news of the entry of the Corona virus into Indonesia directly infected the capital market.

\section{LITERATURE REVIEW}

[7]Jogiyanto (2009) stated that the information published as an announcement will provide a signal for investors in investment decision making. If the announcement contains positive value, then it is expected that the market will react when the announcement is received by the market. The market reaction was indicated by a change in the volume of stock trading. When the information is announced and all market participants have received the information, market participants first interpret and analyze the information as a good news signal or bad news. The result of interpretation of this information will affect the demand and supply of investors.

The study of events is part of the concept of efficient market hypothesis.Event studies are a form of study to test the efficiency of the semi-strong form market. More specifically, event studies investigate the market's response to the content of information from an announcement or publication of a particular event. The content of information can be either good news or bad news. The efficient market hypothesis predicts that the market will give a positive market response to good news, and a negative response to bad news. The market response is reflected in positive abnormal returns (good news) and abnormal negative returns or bad news[17] (Tandelilin, 2010).

Market efficiency means that market participants will move together following the changes that occur. The changes occurred in the form of information that was absorbed or responded by the market efficiently. Efficiently means that every market player does not spend a lot of money to be informed so that they can react appropriately and quickly in the formation of a new price balance. This new price balance reflects the information available in the market. If the market doubts the correctness of an information, then there will be a late or earlier response because there are investors who are more willing to speculate and there are investors who prefer to wait until a certain time. How the market reacts to an event based on public information is known as the study of events [17](Tandelilin, 2010).

Event studies are studies that study market reactions to an event whose information is published as an announcement. Event study can be used to test the information content of an announcement and can also be used to test the efficiency of a semi-strong form market[7] (Jogiyanto, 2016).

Information content testing and semi-strong form market efficiency testing are two different tests. Testing the content of information is intended to see the reaction of an announcement. If the announcement contains information, it is expected that the market will be in contact at the time the announcement is received by the market. This reaction can be measured by return as the value of price change or by using abnormal return. If used abnormal return, then it can be said that an announcement that has information content will give abnormal return to the market. On the contrary, those that do not contain information do not provide abnormal returns to the market[7] (Jogiyanto, 2016).Events that are the focus of research can be grouped into several types, among others most commonly found in the study of events according to [17]Tandelilin:2010) are:

1) Conventional Event Studies

Conventional event studies study market responses to frequent events and are publicly announced by issuers in the capital market. Some examples of conventional event studies include: profit announcements, dividend payments, right issue, mergers and acquisitions, capital spending announcements, stock splits, and other similar forms.

\section{2) Cluster Event Studies}

Cluster or group event studies study market responses to openly announced events that occur at the same time and impact a particular company. For example, cluster events are government announcements that make regulations on certain industries, so that it is expected to have an impact on the cash flow of companies in the industry concerned.

3) Study of Unexpected Events

This study studied the market's response to an unanticipated event. As the name implies, the main characteristic of this study is that events that occur are unpredictable. Research on unexpected events has not been done much, apart from the nature of rare events, not all unexpected events are relevant to the study of events related to the capital market.

4) Sequential Event Study

The study studied the market's response to a series of events that occur sequentially in situations of high uncertainty. In this case the speed and accuracy of information is key to the market response.

Abnormal return

Abnormal return is the return obtained by investors that is not in accordance with expectations. Abnormal return is the difference between the expected return and the return obtained. The difference in return will be positive if the return obtained is greater than the expected return or the calculated return. While the return will be negative if the return obtained is less than the expected return or the return is calculated. Abnormal returns can occur due to certain events, such as public holidays, the beginning of the month, uncertain political atmosphere, extraordinary events, stock splits, initial public offerings, and others.

Event studies analyze abnormal returns from securities that may occur around the announcement of an event. Abnormal return is an advantage of return that actually occurs against normal return. Abnormal return is the difference between the real return that occurs with the expected return,[7] (Jogiyanto, 2016).

Return realization or return is actually a return that occurs at the t-time which is the difference in price now relative to the previous price, while the expected return is an expected return (estimated) using the estimation model.

According to Brown and Warner (1985) in [7](Jogiyanto :2016) estimated the expected return using the estimated 
model of mean-adjusted model, market model and market adjusted model.

Mean-adjustedmodel This mean-adjusted model assumes that the expected return is of a constant value equal to the average return of the previous realization during the estimation period. Market Model

the calculation of expectation return with market model is done by two stages, namely (1) forming the expectation model by using realization data during the estimation period and (2) using this expectation model to estimate the expected return in the window period. Expectential models can be formed using OLS (Ordinary Least Square) regression techniques.

Market-Adjusted Model

The market adjusted model considers that the best guesser for estimating a security's return is the return of the market index at that time. By using this model, it is not necessary to use the estimation period to form an estimation model, because the estimated return of securities is the same as the market index return[7] (Jogiyanto, 2016).

According to [17]Eduardus Tandelilin (2010) abnormal returns are calculated by reducing the market return on the day $\mathrm{t}\left[(\mathrm{R}]_{-}(\mathrm{M}, \mathrm{t})\right)$ of the stock return, as shown in the following equation: [AR \_(i,t)=R_(i,t) R_(M,t)

Trading Volume Activity

Trading volume is an accepted part of technical analysis. Trading activities in very high volumes on an exchange will be interpreted as a sign the market will improve. The increase in stock trading volume coupled with the price increase is a symptom of stronger good conditions. The volume of stock trading can be used by investors to see if the purchased stock is an actively traded stock in the market.

Changes in stock trading volume in the capital market indicate stock trading activity on the exchange and reflect investment decisions by investors. Stock trading volume is measured by stock trading activities (Trading Volume Activity).

[10]Nurmasari (2020) examines the impact of Covid-19 on Changes in Share Price and Transaction Volume (Case Study on PT. Ramayana Lestari Sentosa, Tbk.), the results stated that there were significant differences in the share price and volume of stock transactions before and after the announcement of the first case of covid-19 in Indonesia.

[8]Junaedi and Salistia (2020) conducted research on the impact of the Covid-19 pandemic on capital markets in Indonesia: Composite Stock Index (JCI) Case Study, the results of which stated that the movement of composite stock index (JCI) on the Indonesia Stock Exchange was influenced by internal and external conditions. Internally, the Covid-19 pandemic and social distancing (WFH and PSBB) policies in the country affect the dynamics of the capital market (indicated by the movement of JCI index in idx). Externally, the Covid-19 pandemic in China and Spain has affected the dynamics of capital markets in Indonesia (JCI index).

This study conducted a review of the researches that have been done by the two researchers above on different objects, namely companies included in the LQ-45 index.

Types of Research

\section{RESEARCH METHODS}

The type of research in this research is comparative research. Comparative research is a type of research that aims to compare the results of research between two research groups.
There are two terms of the research group, namely two different and unrelated research groups and two interrelated research groups. In this study, examining daily stock trading data of the LQ-45 company regarding the difference in average abnormal returns and trading volume activity before and after the Covid-19 Pandemic in Indonesia on March 2, 2020 at the LQ-45 company on the IDX.

Population and Sample

In this study the population is the companies whose shares are included in the Indonesia Stock Exchange.In this study, the sample is determined using non-probability sampling (nonprobability sampling) is a sampling technique that does not provide equal opportunities / opportunities for each element or member of the population to be selected as samples [15](Sugiyono, 2008). In determining the sample, researchers used purposive sampling technique. The sample selection is done by using purposive sampling method, which means that the population to be sampled is in accordance with what the researcher wants. The criteria for stocks that will be used in the study to be used as research samples are as follows

a. Shares are listed as issuers on the Indonesia Stock Exchange (IDX) which are included in the LQ-45 group of companies during the research period.

b.Shares are actively traded during the research period. c.Shares do not experience corporate action, namely the issuance of rights, stock spills, bonus shares, and dividend distribution around the research period.

Method of collecting data

The data collection method in this research is the method of documentation obtained from the IDX, the data consists of:

1. Daily share trading volume of each company around the Covid-19 Pandemic in Indonesia on March 2, 2020.

2.The number of shares of each company circulating around the date of the Covid-19 Pandemic in Indonesia on March 2, 2020 .

3. The daily share price of each company around the date of the Covid-19 Pandemic in Indonesia on March 2, 2020, which is the object of research. The share price used is the closing price, which is the price at the end of the exchange.

Research variable

Research variables are anything in the form determined by the researcher to be studied so that information about it is obtained, then conclusions are drawn (Sugiyono, 2008).

Operational definition of a variable

1. Abnormal return

Abnormal return is the difference between the actual return that occurs with the expected return. Abnormal returns are calculated from the 7 days before, during and 7 days after the event for the short term period and 30 days before and after the event for the long term period. The formulation is as follows[7](Jogiyanto, 2016):

$A R_{i t}=R_{i t}-E\left(R_{i t}\right)$

Information :

$A R_{i t}=$ abnormal return of the ith security in the event period $\mathrm{t}$

Rit $=$ actual return that occurs for the ith security in the event period t

$E\left(R_{i t}\right)=$ expected return of the ith security for the event period t

The actual return (actual retrun) is the return that occurs at time $\mathrm{t}$ which is the difference between the current price relative to the previous price ( $\mathrm{t}-1)$ with the study event 7 days before - after and 30 days before - after the event.

$\mathrm{R}(\mathrm{i}, \mathrm{t})=(\mathrm{P}(\mathrm{i}, \mathrm{t})-\mathrm{P}(\mathrm{i}, \mathrm{t}-1)) / \mathrm{P}(\mathrm{i}, \mathrm{t}-1)$ 
Information:

$\mathrm{R}(\mathrm{i}, \mathrm{t})=$ actual stock return $\mathrm{i}$ at time $\mathrm{t}$

$P(i, t)=$ share price $i$ at time $t$

$\mathrm{P}(\mathrm{i}, \mathrm{t}-1)=$ share price at time $\mathrm{t}-1$

Expected return is the return expected by investors that will be obtained in the future where it has not occurred. This study uses a market adjusted model which assumes that the best predictor for estimating the return of a security is the current market index return. By using this model, there is no need to use an

estimation period to form an estimation model, because the estimated return is the same as the market index return [7](Jogiyanto, 2016).

$\mathrm{E}(\mathrm{R}(\mathrm{i}, \mathrm{t}))=\mathrm{R}(\mathrm{M}, \mathrm{t})$

Information:

$E(R(i, t))=$ expected return

$\mathrm{R}(\mathrm{M}, \mathrm{t})=$ market return in period $\mathrm{t}$

2. Volume trading activity of shares

Trading volume activity (TVA) is an instrument that can be used to see the reaction of the capital market to information through parameters of changes in stock trading volume (Neni Meidawati and Mahendra Harimawan, 2004). The TVA calculation results reflect the ratio between the number of shares traded and the number of shares outstanding. Collecting data from a period of 7 days before, during and 7 days after the event for a short-term period and 30 days before and after the event for the long-term announcement of the Covid-19 Pandemic in Indonesia.

TVA $=\Sigma$ Shares $\mathrm{i}$ are traded on day $\mathrm{t} / \Sigma$ Shares are outstanding on day $\mathrm{t}$

\section{DATA ANALYSIS METHOD}

The basis of analysis in this research is an event study. Event studies which can be used to test the information content of an announcement and can also be used to test the efficiency of the semi-strong form market (Jogiyanto, 2016). While the event study in this research is the reaction of the capital market in Indonesia to the Covid-19 Pandemic in Indonesia on March 2, 2020. In this study observes stock price movements on the Indonesia Stock Exchange to analyze the difference in the average abnormal return obtained by investors between before and after. events, and analyze differences in the average stock trading volume activity before and after the event.

Paired Sample Test t Test Abnormal ReturnThe paired sample $\mathrm{t}$ test was carried out to test the difference in average abnormal returns before and after the official announcement from the government about Covid-19. Paired sample t test was performed after the data proved to have passed the normality test.

Theformulation of the hypothesis is: Ho: $\mu 1=\mu 2$ There is no difference in the average abnormal return before and after the official announcement from the government about Covid-19 at LQ-45 companies on the IDX.Ha: $\mu 1 \neq \mu 2$ There is a difference in the average abnormal return before and after the official announcement from the government about Covid-19 at the LQ-45 company on the IDX.The test criteria are:

If theobability (Sig-t) $<0.05$ then Ho is rejectedIf the probability (Sig-t) $>0.05$ then Ho is accepted Paired Sample Test t Test Trading Volume Activity The Paired Sample t test was conducted to test the difference in Average Trading Volume Activity before and after the official announcement from the government about Covid-19.
The t test is carried out after the data is proven to pass the normality test so that the data is normal.

The formulation of the hypothesis is:Ho : $\mu 1=\mu 2$ There is no difference in the average trading volume before and after the official government announcement about Covid-19 at the LQ45 company on the IDX.

Ha : $\mu 1 \neq \mu$ 2There is a difference in the average trading volume before and after the official government announcement about Covid-19 at the LQ-45 company on the IDX.

The test criteria are:

If the probability (Sig-t) $<0.05$ then Ho is rejected If the probability (Sig-t) $>0.05$ then Ho is accepted Results of Data Analysis and Discussion

The test results for the presence or absence of an abnormal return around the official announcement from the government regarding Covid-19 found that there was a significantly negative abnormal return in the days surrounding the announcement. This shows that the government's announcement of the new Covid 19 case for the first time in Indonesia has been responded to or received a negative reaction by the capital market. Share prices on the Indonesia Stock Exchange, including LQ45 companies, experienced a significant declinebecause of the covid-19 case that occurred in Indonesia. On the other hand, to prevent the spread of covid-19, the government asks people to always stay at home. Of course this causes the community to reduce activities in almost all sectors including the closing of the company's operations as a whole, so this of course causes a decrease in turnover at the company. This decrease in income even caused some employees to be laid off. For investors, of course this is a detrimental thing, because investors have a great chance of not getting dividends and can experience capital loss.

From the results of the abnormal return test results show that there is a significant difference between before and after the event The official government announcement about the COVID-19 outbreak in Indonesia on March 2, 2020 for the period (10 days) before and ten (10) days after the announcement, this is proven with the t test result of 2.791 with a probability of 0.008 , which value is much smaller than 0.05 . This means that the first hypothesis in this study can be accepted. If seen from the average value, it shows a negative reaction with a negative average abnormal return after the official government announcement regarding the COVID-19 outbreak in Indonesia on 02 March 2020.

The test results for the average Abnormal stock return in the long-term period, which is 30 before the official government announcement regarding the COVID-19 outbreak in Indonesia on March 02, 2020, is negative $(-0.002043)$ lower than the average abnormal return in the period after announcement (0.001469). This difference was statistically significant. This is evidenced by the results of the $t$ test of -2.903 with a probability of 0.006 , which is much smaller than 0.05 .

These results indicate that the official government announcement about the COVID-19 outbreak in Indonesia on March 2, 2020 brought bad news, thus affecting stock prices and LQ-45 which experienced a decline after the announcement. This has been responded badly by the market so that stock prices have decreased, including the leading stocks that are included in the LQ-45 group, thus lowering stock prices

The results of the research conducted indicate that the average abnormal return for the period before and after the 
announcement has a significant difference in the average abnormal return of stocks. This indicates that there is useful information about events so that the capital market reacts. Capital market players consider that this event is an event that can affect the value of their investment, so that there are investors who have more information to get an abnormal return.

Based on the results of data analysis, it is stated that the average share TVA in the 10 day period prior to the official government announcement regarding the COVID-19 outbreak in Indonesia on 02 March 2020 was (0.001495) lower than the average TVA shares after the official government announcement regarding the COVID-19 outbreak in Indonesia on March 2, 2020, namely (0.001740). Statistically this difference is significant, this is evidenced by the t test results, which is equal to -2.217 with a probability of 0.032 which is less than $0.05(\mathrm{p}<0.05)$.

Long-term testing shows that the average share TVA in the 30 day period prior to the official government announcement regarding the COVID-19 outbreak in Indonesia on 02 March 2020 was (0.001369) lower than the stock TVA average 30 days after the official announcement. government regarding the COVID-19 outbreak in Indonesia on March 2, 2020, which is (0.002327). Statistically this difference is significant, this is evidenced by the results of the t test, which is equal to -3.636 with a probability of 0.001 which is less than 0.05 ( $p<0.05)$.

Thus it can be stated that there is a significant difference in the average trading volume between before and after the official government announcement about Covid-19 at the LQ-45 company on the IDX.

There was an increase in stock trading volume after the official government announcement regarding the COVID-19 outbreak in Indonesia on March 02, 2020, both in the short and long term, because the market gave a negative response to the announcement, so that many investors released their shares, resulting in an increase in transaction volume, because is expected to disrupt real business for the foreseeable future so investors reacted to the announcement.

\section{V.CONCLUSION}

Based on the data analysis, it can be concluded that:

1. There is a significant difference in the average abnormal return for both the short and long term periods on LQ-45 shares listed on the IDX between before and after the official announcement from the government regarding the COVID-19 outbreak in Indonesia. This difference indicates that the abnormal return after the announcement has been responded negatively by the market.

2. There is a significant difference in the average trading volume for both short and long term periods in LQ-45 shares listed on the IDX between before and after the official government announcement about the COVID-19 outbreak in Indonesia. This shows that the announcement of the Covid-19 Pandemic in Indonesia has had a significant impact on stock liquidity.

\section{REFERENCES}

[1] Arifin Ali, 2007 Bacalahtentangsaham, panduandasarseniberinvestasi dan teoripermainansaham. Kapan beli, kapanjual, Andi, Yogyakarta.

[2] Darmadji, Tjiptono dan Hendy M.F, 2001. Pasar Modal di Indonesia, SalembaEmpat, Jakarta.

[3] Darmaji, T., \& Fakhruddin, H. M. (2006). Pasar Modal di Indonesia: Pendekatan Tanya Jawab. Jakarta: SalembaEmpat

[4] Engelhardt N, Krause M, Neukirchen D., Posch P, (2020) Apa yang MendorongSahamSelamaJatuhnya Korona? PerhatianBerita vs.
HarapanRasional, Keberlanjutan 2020, 12, 5014; doi: 10.3390 / su12125014

[5] Haryanto, 2020, Dampak Covid-19 terhadapPergerakan Nilai Tukar Rupiah dan IndeksHargaSahamGabungan (IHSG), JurnalPerencanaan Pembangunan Indonesia Volume IV No.2, hal: 151 - 165

[6] Jones, P. C. (2013). Analisis dan ManajemenInvestasi(edisi ke-12). Carolina Utara: Wiley

[7] Jogiyanto. H., 2016. TeoriPortofolio dan AnalisisInvestasi (edisi ke-11), BPFE Yogyakarta.REFERENCES

[8] Junaedi D., Salistia F., (2020), DampakPandemi Covid-19 terhadap Pasar Modal di Indonesia: StudiKasusIndeksSahamGabungan (IHSG), AlKharaj: JurnalEkonomiIslam ,Keuangan\&Bisnis, Volume 2 Nomor 4, hlm.: 1-30

[9] Kiky Andreas (2020), ManajemenRisiko Acara Black Swan Maret 2020 di Indonesia. StudiKasusPengaruh Covid-19 di Pasar Modal Indonesia, Jurnal Bina Manajemen, Maret 2020, Vol. 8 No.2 Halaman 90 - 105

[10] Nurmasarilfa (2020), Dampak Covid-19 TerhadapPerubahanHargaSaham dan Volume Transaksi (StudiKasus pada PT. Ramayana Lestari Sentosa, Tbk.), JurnalSekuritas (Saham, Ekonomi, Keuangan dan Investasi) Vol . 3, No. 3, Halaman: 230 - 236.

[11] Putri T.N.A, dan Amanah H.J.J. (2020) Reaksi Pasar Modal Indonesia TerhadapFluktuasi Rupiah PascaPandemi Covid-19 (Studi Perusahaan yang Terdaftar di LQ45 di Bursa Efek Indonesia), e-journal FakultasEkonomi dan BisnisUniversitasBrawijaya

[12] Rivai, V., \& et al. (2008). PenilaianKinerja. Jakarta: PT. Raja GrafindoPersada

[13] Rusdin, 2006. Pasar Modal, TeoriMasalah dan KebijakandalamPraktek, Alfabeta, Bandung.

[14] ReaksiSundariVini 2011 Pasar Modal Indonesia TerhadapPenyelenggaraanPemilihanUmum 9 April 2009 di Bursa Efek Indonesia, E-Journal UniversitasGunadarma

[15] Sugiyono, 2008. Penelitian dan MetodeBisnis, Alfabeta, Bandung.

[16] Sharpe, Wiliam F, dkk, 2005. Investasi (Pristina Hermastuti dan TerjemahanDoddyPrastuti), Indeks, Jakarta.

[17] TandelilinEduardus, 2010. Teori dan AplikasiPortofolio dan Investasi, PenerbitKanisius, Yogyakarta.

[18] Zaremba A, Kizys R., Aharon D.Y., dan Demir E., (2020), Pasar Terinfeksi: Novel Coronavirus, IntervensiPemerintah, dan VolatilitasPengembalianSaham di Seluruh Dunia, JurnalPra-Bukti

[19] Engelhardt N, Krause M, Neukirchen D., Posch P, (2020) Apa yang MendorongSahamselamaJatuhnya Korona? 